\title{
Weed Flora in Dill (Anethum graveolens L., Apiaceae, Apiales) Grown in Conventional and Organic Production Systems
}

\author{
Branka Ljevnaić Mašić · Dejana Džigurski · Ljiljana Nikolić · \\ Milka Brdar Jokanović · Dušan Adamović
}

\begin{abstract}
Summary: This study was performed to compare the weed flora in dill crops maintained conventionally and according to the principles of organic production. Out of 17 weed species noted for the two growing systems, even four (Amaranthus retroflexus L., Datura stramonium L., Sorghum halepense (L.) Pers., and Veronica persica Poir.) are invasive in Vojvodina region (Serbia). Weed infestation (number of individuals per $\mathrm{m}^{2}$ ) was significantly higher on the conventional plots $\left(\mathrm{p}=0.0000^{* *}\right)$. The dominating species in conventional growing system were Convolvulus arvensis, Veronica persica and Chenopodium album (8.00, 6.67 and 5.33 individuals per $\mathrm{m}^{2}$, respectively), while Amaranthus retroflexus dominated on organic plots (8.00 individuals per $\mathrm{m}^{2}$ ). Regarding life forms of the recorded weed flora, therophytes dominate both in conventional $(92.31 \%)$ and organic $(66.67 \%)$ systems. The observed differences in weed flora are due to the specificities of dill conventional and organic production.

Keywords: Anethum graveolens, conventional crop production, dill, organic crop production, weed
\end{abstract} infestation, weeds

\section{Introduction}

Dill (Anethum graveolens L., Apiaceae) is an annual plant with short vegetation period of approximately 90 days and therefore can be planted several times during the year. It originates from Southeast Asia and can be successfully cultivated in Southern Europe (Đurovka 2008). Containing A, C, B2, B3 and B9 vitamins, as well as minerals such as $\mathrm{Cu}, \mathrm{K}, \mathrm{Ca}, \mathrm{Mn}, \mathrm{Fe}$ and $\mathrm{Mg}$, dill has been used as a medicinal plant for a long period of time. Essential oil is considered as an anesthetic, sedative, antiseptic, and as useful in lowering blood sugar level. Therefore, dill oil is used for relieving problems related to the digestive tract, insomnia, bladder inflammation, respiratory system, hypertension, and as an appetizer. Although the ripe fruit contains the highest amount of the biologically active and aromatic compounds, young juicy branches are the most commonly used as a spice (Tucakov 1997).

Dill has moderate requirements for temperature and light, $15-17^{\circ} \mathrm{C}$ is optimal. It is a long-day plant, in low light it grows abnormally in

B. Ljevnaić Mašić* · D. Džigurski · Lj. Nikolić

University of Novi Sad, Faculty of Agriculture, Trg D. Oradoviča 8, 21000 Novi Sad, Serbia

e-mail: brana@polj.uns.ac.rs

Milka Brdar-Jokanović · Dušan Adamovic

Institute of Field and Vegetable Crops, Maksima Gorkog 30, 21000 Novi Sad, Serbia height and contains smaller amounts of aromatic compounds (Đurovka 2008). In the initial phases of development dill has high water demands; later is more tolerant to drought since the more mature plants make shadow, preventing soil moisture loss. It is recommended to grow dill on loose soils of slightly acid to slightly alkaline $\mathrm{pH}$ (Kišgeci 2002).

An important dill crop protection measure is weed control. Weeds can exhibit negative effects on quality of dill essential oil, by the means of the unpleasant odour, taste and colour. This study was undertaken in order to investigate the weed flora in conventionally and organically grown dill, which is a necessary precondition for choosing the weed control measure applicable for the specific production system.

\section{Material and Methods}

The weed flora analysis included dill (Anethum graveolens L.) crops grown in the conventionally and organically maintained experimental fields of the Institute of Field and Vegetable Crops, Novi Sad, Alternative Crops Department, Bački Petrovac, Serbia. The survey was conducted during dill growing season of 2014. Sowing was performed in the late April with row spacing of $70 \mathrm{~cm}$.

Acknowledgements: This work was supported by the Ministry of Education, Science and Technological Development of the Republic of Serbia (Research Grant: TR-31027). 
Mineral fertilizer was applied in conventional plots in November 2013 (15:15:15 NPK, $\left.400 \mathrm{~kg} \mathrm{ha}^{-1}\right)$. Organic plots were fertilized in November 2011 with farmyard manure applied at the rate of $15 \mathrm{t} \mathrm{ha}^{-1}$. Other cultivation practices were not performed. Preceding crop was white mustard (Sinapis alba L.).

Weed infestation (number of individuals per square meter, no. of ind. $/ \mathrm{m}^{2}$ ) was determined by counting weed species occurring in crop sections of $\mathrm{m}^{2}$. The counting was performed in three replications for both production systems.

The recorded weed species were identified according to Josifović (1970-1977), and life forms according to Ujvárosi (1973). The data were processed by ANOVA procedure, using Fisher LSD for comparison of means. Statistica 7.0 (StatSoft, OK, USA, Novi Sad University License) software package was used.

\section{Results and Discussion}

Weed flora occurring in dill crops maintained conventionally $(\mathrm{CP})$ and according to the principles of organic production (OP) consisted of 17 taxa in total; 15 broad-leaved (class Magnoliopsida) and two narrow-leaved (class Liliopsida). Out of 17 recorded weeds, four are invasive for the Vojvodina region of Serbia (IASV 2011): Amaranthus retroflexus L., Datura stramonium L., Sorghum halepense (L.) Pers. and Veronica persica Poir. (Tab. 1). Since invasive weed species may exhibit extremely negative effects on crops and autochthonous flora, it is necessary to monitor their number in order to prevent uncontrolled spreading (Moody \& Mack 1988, Pearson \& Dawson 2003, Vrbničanin et al. 2004, Džigurski et al. 2012).

Thirteen weed species were found in conventional crops, while the flora recorded in organic crops consisted of nine weeds. The species Amaranthus retroflexus, Bilderdykia convolvulus, Chenopodium album, Convolvulus arvensis and Senecio vulgaris were noted in both growing systems. The remaining 12 species are differential, i.e. occurring in one production system only.

Dill crop weed infestation was generally low for both growing systems (5-10\%), with Convolvulus arvensis $\left(8.00\right.$ ind. $\left./ \mathrm{m}^{2}\right)$, Veronica persica $\left(6.67 \mathrm{ind} . / \mathrm{m}^{2}\right)$ and Chenopodium album (5.33 ind. $/ \mathrm{m}^{2}$ ) dominating on conventional plots, and Amaranthus retroflexus (8.00 ind. $/ \mathrm{m}^{2}$ ) on organic plots.

Table 1. Life forms, average weed infestation (no. of ind. $/ \mathrm{m}^{2}$ ) and $\mathrm{p}$-values from the LSD test comparing the mean weed infestation in conventional (CP) and organic (OP) dill production systems

\begin{tabular}{lcccc}
\hline Plant species & Life form & Average weed infestation & p-value \\
\hline - Amaranthus retroflexus & & $\mathrm{CP}$ & $\mathrm{OP}$ & $0.0101^{*}$ \\
Bilderdykia convolvulus & $\mathrm{T}_{4}$ & 2.67 & 8.00 & 0.5447 \\
Chenopodium album & $\mathrm{T}_{4}$ & 1.33 & 1.33 & 0.1803 \\
Convolvulus arvensis & $\mathrm{T}_{4}$ & 5.33 & 1.71 & $0.0167^{*}$ \\
- Datura stramonium & $\mathrm{G}_{3}$ & 8.00 & 1.14 & 0.2165 \\
Fumaria officinalis & $\mathrm{T}_{4}$ & - & 1.71 & 0.1328 \\
Hibiscus trionum & $\mathrm{T}_{3}$ & 1.33 & - & 0.1328 \\
Lamium amplexicaule & $\mathrm{T}_{4}$ & 1.33 & - & $0.0101^{*}$ \\
Matricaria chamomilla & $\mathrm{T}_{1}$ & 2.67 & - & $0.0101^{*}$ \\
Polygonum aviculare & $\mathrm{T}_{2}$ & 2.67 & - & 0.1328 \\
Senecio vulgaris & $\mathrm{T}_{4}$ & 1.33 & - & 0.5447 \\
Setaria glauca & $\mathrm{T}_{1}$ & 1.33 & 1.33 & 0.1328 \\
Solanum nigrum & $\mathrm{T}_{4}$ & 1.33 & - & 0.1328 \\
Sonchus arvensis & $\mathrm{T}_{4}$ & 2.67 & - & 0.5447 \\
Sorghum balepense & $\mathrm{G}_{3}$ & - & 1.33 & 0.4474 \\
Stachys annua & $\mathrm{G}_{1}$ & - & 2.86 & 0.5447 \\
- Veronica persica & $\mathrm{T}_{4}$ & - & 1.71 & $0.0134^{*}$ \\
\hline Total no. of ind./m & $\mathrm{T}_{1}$ & 6.67 & - & $0.0000^{*}$ \\
\hline Total no. of species & 17 & 38.66 & 13 & 9 \\
\hline
\end{tabular}

- - invasive species in the Vojvodina region; * - significant at the 0.05 level of probability 
Table 2. Life forms of the weed flora from dill crops grown in conventional (CP) and organic (OP) production systems

\begin{tabular}{|c|c|c|c|c|c|}
\hline \multirow[t]{2}{*}{ Plant life form } & & \multirow{2}{*}{$\begin{array}{c}\text { CP } \\
\text { No. of species }\end{array}$} & \multicolumn{3}{|c|}{ OP } \\
\hline & & & $\%$ & No. of species & $\%$ \\
\hline \multirow[t]{4}{*}{ Therophytes $-\mathrm{T}$} & $\mathrm{T}_{1}$ & 3 & 23.08 & 1 & 11.11 \\
\hline & $\mathrm{T}_{2}$ & 1 & 7.69 & - & - \\
\hline & $\mathrm{T}_{3}$ & 1 & 7.69 & - & - \\
\hline & $\mathrm{T}_{4}$ & 7 & 53.85 & 5 & 55.56 \\
\hline$\Sigma$ & & 12 & 92.31 & 6 & 66.67 \\
\hline \multirow[t]{2}{*}{ Geophytes - G } & $\mathrm{G}_{1}$ & - & - & 1 & 11.11 \\
\hline & $\mathrm{G}_{3}$ & 1 & 7.69 & 2 & 22.22 \\
\hline$\Sigma$ & & 1 & 7.69 & 3 & 33.33 \\
\hline Total & & 13 & 100.00 & 9 & 100.00 \\
\hline
\end{tabular}

Average weed infestation was significantly lower $\left(\mathrm{p}=0.0000^{* *}\right)$ for organic crops. According to Nikolić et al. (2013) who also reported comparatively low weed infestation for organically maintained potato crops, the result might be related to the unbalanced ecological conditions in the organic system, as well as by partial isolation of these plots. Nevertheless, Weibull et al. (2003) state that the variation in weed flora found in different agricultural production systems is yet to be explained. Annual therophyte Amaranthus retroflexus was more numerous on organic plots $\left(\mathrm{p}=0.0101^{*}\right)$; vice versa, geophyte Convolvulus arvensis occurred in a higher number on conventional plots $\left(p=0.0167^{*}\right)$.

Plant life forms found in the investigated agro ecosystem are an excellent indicator of their adaptation to the respective synecological factors. Annual herbaceous plants which survive unfavorable seasons in the form of seeds i.e. therophytes (T) dominate in both production systems (CP - 12 species, 92.31\%; OP - six species, 66.67\%), Table 2, Figure 1. Amongst the recorded therophytes, $\mathrm{T}_{4}$ are the most numerous. Those are the plants that germinate in spring and whose seed mature in late summer. This is typical for ecosystems which are under strong anthropogenic influence and implies the instability of the weed flora, related to the applied cultivation practices (Kojić et al. 1988, Kovačević 2008).

Geophytes are herbaceous plants which survive the winter by forming underground stems (rhizomes, bulbs, tubers); their presence implies the stability of the weed flora. In our study, geophytes were less numerous than the therophytes; however, their occurrence was more frequent in the crops maintained according to the principles of organic production (CP - one species, 7.69\%; OP - three species, 33.33\%), as shown in Table 2, Figure 1.

The knowledge of the biological spectrum of weed flora is important for determining the manner and time of taking appropriate measures for their control. The differences in weed flora between the two production systems are due to the cultivation practices specific for growing medicinal and spice plants in conventional and organic production systems.

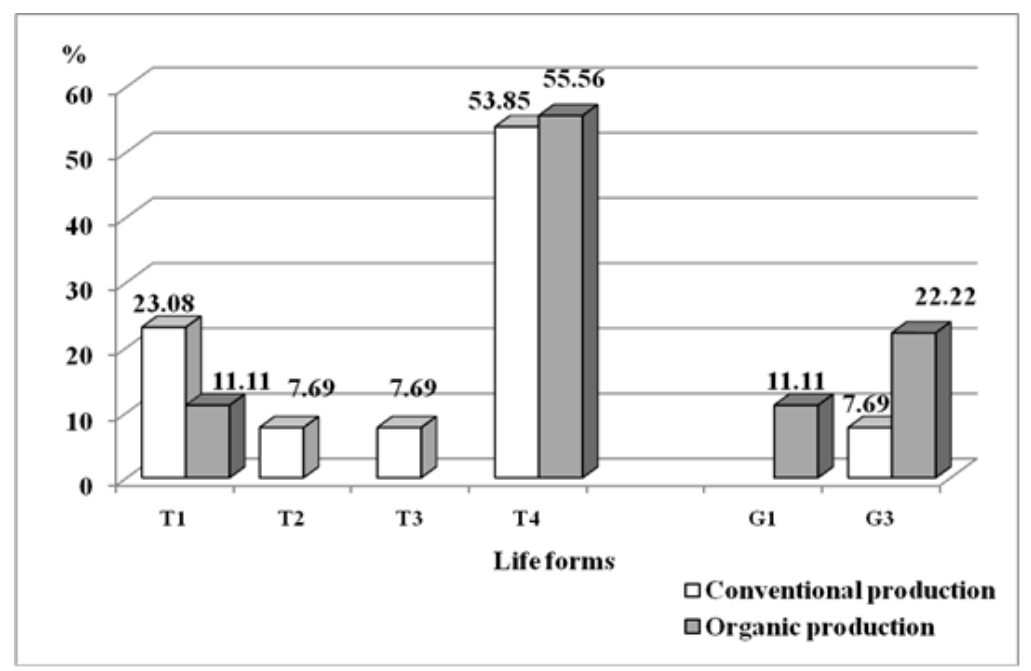

Figure 1. The percentage of therophytes and geophytes in conventional (CP) and organic (OP) dill production 


\section{Conclusions}

Weed flora in dill grown on conventionally and organically maintained plots consisted of 17 taxa (15 broad-leaved and two narrow-leaved weeds), four of which are invasive for the Vojvodina region (Amaranthus retroflexus L., Datura stramonium L., Sorghum halepense (L.) Pers. and Veronica persica Poir.). Since invasive weeds may affect cultivated plants, it is important to monitor their number in order to prevent uncontrolled spreading. Thirteen weed species have been noted in conventionally grown dill, while the weed flora found on the organically grown plots consisted of nine species. The analysis of the average weed infestation showed significantly lower values $(p$ $=0.0000^{*}$ ) for organically maintained dill. Convolvulus arvensis (8.00 ind. $\left./ \mathrm{m}^{2}\right)$, Veronica persica (6.67 ind. $/ \mathrm{m}^{2}$ ) and Chenopodium album (5.33 ind. $/ \mathrm{m}^{2}$ ) dominated on the conventional, while Amaranthus retroflexus (8.00 ind. $/ \mathrm{m}^{2}$ ) dominated on the organic plots.

Regarding biological spectrum of the weeds, only therophytes and geophytes were found. Therophytes dominated in both production systems (CP - 12 species, $92.31 \%$; OP - six species, 66.67\%), implying the instability of the weed flora. Geophytes were less numerous; however, their occurrence was more frequent in organic crops (CP - one species, 7.69\%; $\mathrm{OP}$ - three species, $33.33 \%$ ). The knowledge of the biological spectrum of weeds is important for determining the manner and time of taking appropriate measures for their control.

\section{References}

Anačkov, G., Bjelić-Čabrilo, O., Karaman, I., Karaman, M., Radenković, S., Radulović, S., Vukov, D. \& Boža, P. (2011). [ASV] Lista invazivinib vrsta na području AP Vojvodine = List of invasive species in AP Vojvodina [Internet]. Version 0.1beta. [cited 2014 July 17]. Available from: http:// iasv.dbe.pmf.uns.ac.rs/. Department of Biology and Ecology, Novi Sad.

Džigurski, D., Ljevnaić-Mašić, B., \& Nikolić, Lj. (2012). Invazivne biljke korovske flore u organskoj poljoprivredi. Acta Biologica Iugoslavica: Acta herbologica, 21(1): 21-29.

Đurovka, M. (2008). Gajenje povría na otvorenom polju. Faculty of Agriculture, Novi Sad.

Josifović, M. (Ed.) (1970-1977). Flora SR Srbije, I-IX, SANU, Beograd, Srbija.

Kišgeci, J. (2002). Lekovito bilje - Gajenje, sakupljanje, upotreba. Partenon, Beograd.

Kojić, M., Šinžar, B., \& Stepić, R. (1988). Korovska vegetacija severozapadne Srbije. Zbornik radova Poljoprivrednog fakulteta, 32 -33(589): 83-107.

Kovačević, D. (2008). Njiuski korovi - biologija i suz̧bijanje. Univerzitet u Beogradu, Poljoprivredni fakultet-Zemun, Beograd-Zemun.

Moody, M., \& Mack, R. (1988). Controlling the spread of plant invasions: The importance of nascent foci. J. Appl. Ecol., 25: 1009-1021.

Nikolić, Lj., Ilić, O., Džigurski, D., \& Ljevnaić-Mašić, B. (2013). Analysis of weed flora in conventional and organic potato production. Biologica Nyssana, Journal of Biological Science, 4(1-2): 9-14.

Pearson, R.G., \& Dawson, T.E. (2003). Predicting the impacts of climate change on the distribution of species: are bioclimate envelope models useful? Global Ecol. Biogeogr., 12(5): 361-371. DOI: 10.1046/j.1466-822X.2003.00042.x.

Tucakov, J. (1997). Lecenje biljem - fitoterapija. Beograd.

Ujvárosi, M. (1973). Gymnövények. Mezőgazdasági Kiado, Budapest.

Vrbničanin, S., Karadžić, B., \& Dajić-Stevanović, Z. (2004). Adventivne i invazivne korovske vrste na području Srbije. Acta Biologica Ingoslavica: Acta berbologica, 13(1): 1-12.

Weibull, A. C., Östman, Ö., Granqvist, A. (2003): Species richnes in agroecosystems; the effect of landscape, habitat and farm management. Biodiversity and Conservation, 12: 1335-1355.

\section{Uporedna analiza korovske flore u konvencionalnoj i organskoj proizvodnji mirođije (Anethum graveolens L., Apiaceae, Apiales)}

\section{Branka Ljevnaić Mašić · Dejana Džigurski · Ljiljana Nikolić · Milka Brdar Jokanović · Dušan Adamović}

Sažetak: Uporednom analizom korovske flore u usevu mirođije gajenom po principima konvencionalne (CP) i organske proizvodnje (OP) konstatovano je ukupno 17 korovskih vrsta, od čega su četiri (Amaranthus retroflexus L., Datura stramonium L., Sorghum halepense (L.) Pers. i Veronica persica Poir.) invazivne za područje Vojvodine. Analizom prosečne zakorovljenosti (broj individua po $\mathrm{m}^{2}$ ) mirođije u oba sistema gajenja, utvrđena je značajno veća zakorovljenost u usevu gajenom prema CP $\left(\mathrm{p}=0.0000^{*}\right)$. U CP mirođije dominiraju Convolvulus arvensis $(8.00$ ind. $/ \mathrm{m}^{2}$ ), Veronica persica (6.67 ind. $/ \mathrm{m}^{2}$ ) i Chenopodium album (5.33 ind. $/ \mathrm{m}^{2}$ ), dok Amaranthus retroflexus značajno dominira u OP sa 8.00 ind. $/ \mathrm{m}^{2}$. Biološki spektar pokazuje dominaciju terofita u oba sistema gajenja (CP 92,31\%; OP - 66,67\%). Razlike u strukturi korovske flore su vezane za specifičnosti gajenja mirođije u konvencionalnom i organskom sistemu proizvodnje.

Ključne reči: Anethum graveolens, konvencionalna proizvodnja, korovi, mirođija, organska proizvodnja, zakorovljenost 